\title{
Assessing the Use of Hillside Rainwater Harvesting Ponds on Agricultural Production, a Case of Unicoopagi Cooperative Union
}

\author{
Jean Baptiste Safari, Maniragaba Abias, Christophe Mupenzi \\ Department of Environmental Economics and Natural Resources Management, University of Lay Adventists of Kigali, Kigali, Rwanda \\ Email address: \\ safjean2002@yahoo.fr (J. B. Safari)
}

\section{To cite this article:}

Jean Baptiste Safari, Maniragaba Abias, Christophe Mupenzi. Assessing the Use of Hillside Rainwater Harvesting Ponds on Agricultural Production, a Case of Unicoopagi Cooperative Union. International Journal of Natural Resource Ecology and Management.

Vol. 5, No. 2, 2020, pp. 64-71. doi: 10.11648/j.ijnrem.20200502.15

Received: May 13, 2020; Accepted: June 15, 2020; Published: June 29, 2020

\begin{abstract}
This research was conducted on the assessment of the use of hillside rainwater harvesting ponds on Agricultural Production in Unicoopagi cooperative union located in Nyamigina cell, Tare sector of Nyamagabe District. The research involved both primary and secondary data. The primary data was collected using questionnaire, interview and observation while secondary data was derived from existing document dealing with rainwater harvesting pond at national and worldwide. The results from collected data showed that the level of adoption of rain water harvesting ponds was used by $51.5 \%$ farmers; the main reason of failing level of RWH ponds is due to small plot size of farmers; and the main factors contributing to the use of this technology include land acquisition and irrigation. It is further revealed that the use of rain water harvesting pond impacted positively; the agriculture production on 0.5 hectares per 4 years, has generated the income of $17,772,800$ Rwandan Francs for non-irrigated plot, while the same plot irrigated with the use of rain water harvested the income increased up to 20,296,450 Rwandan Francs. Beside this rain water harvesting ponds has some observed negative effect among water users that include social conflicts, accident and breeding of mosquitoes with percentage equivalent to $41 \%, 27 \%$ and $32 \%$ respectively. The analysis of variance (ANOVA) results show that the amount of agriculture production and generated income was significantly different between adopted and non-adopted rain water harvesting techniques. The implication of these findings is that the adoption of rainwater harvesting ponds presents a way forward for reducing rural poverty. With the increase of rainfall variability and evaporation due to climate change, rain water harvesting will become a key intervention in adaptation and in reducing vulnerabilities of crop water stress. Therefore, extent knowledge in RWH techniques needs to be considered as an important, manageable resource in water management policies, strategies and plans. Considering that farmer's perception in increasing crop yield is due to rain water harvesting, this will encourage the adoption of this techniques. Thus for the RWH techniques to be effective and bring higher return to farmers, it should goes hand in hand with other improved agriculture Techniques and Agro- inputs uses such as Land consolidation, improved seeds, pesticide and fertilizers.
\end{abstract}

Keywords: Agriculture Production, Irrigation, Pond, Rain Water Harvesting

\section{Introduction}

The livelihood of a major proportion of population in the developing world is connected to agriculture productivity either directly or indirectly, In 2011 World Bank reported that, 2.5 billion people depend on agriculture as their main sources of livelihood and among them 1.3 billion people are small farmers and landless workers, $75 \%$ of world poor population are living in rural areas and $86 \%$ of them work in agricultural sector for their livelihood [1].

Low agriculture productivity is causing food shortage across the world, It is necessary to know about the obstacles, to increase agricultural productivity in Sub-Saharan Africa include that of non-Adoption, inadequate access and nonefficiency management of Rain water harvesting or the collection of rainwater in a proper way, as this can be a sustainable solution to the problem of water crisis in different parts of the world [2]. 
In Rwanda, about $80 \%$ of population depend on agriculture. However, agricultural activities in the country are largely subsistence-based and this therefore affects economic development. Due to the population increase in the highland areas, more and more marginal areas are being used for agriculture which led to the degradation of the natural resources. One of the major challenges to rural development in the country is how to promote food production to meet the ever-increasing demand of the growing population due to the fact that rainfall in the arid and semi-arid areas is generally insufficient to meet the basic needs of crop production. In degraded areas with poor vegetation cover and infertile soil, rainfall is lost almost completely through direct evaporation or uncontrolled runoff. Various technologies of rainwater harvesting (such as RWH ponds, dam reservoirs, groundwater recharge, etc.) are available, through which rainwater is captured, stored and used at the time of water scarcity [3]

Rwanda's main limiting production factor in agriculture is land [4]; Agriculture growth requires an increase in profits per hectare and capture of productivity gains along the value chain. To raise profits per hectare means increasing agricultural yields and switching to higher value agricultural commodities, the development of new irrigated land and the sustainable mobilization of water for agriculture involve a series of actions. These include marshland irrigation, hillside irrigation, protected (green house) irrigation, small scale irrigation and water development. Small scale irrigation and water development offer the advantage to be easily adopted by farmers and be simple to manage. They include small ponds and check dams (water harvesting), reservoirs for fish (aquaculture), livestock watering and other productive activities [5].

Rainwater harvesting (RWH) locally collects and stores rainfall through different technologies for future use to meet the demands of human consumption or human activities [6].

The art of rainwater harvesting has been practiced since the first human settlements. It has been a key entry point in local water management, buffering supplies of rainfall to service the human demand of freshwater. As it involves the alteration of natural landscape water flows, it requires water managers to carefully consider the tradeoffs. However, it can create multiple benefits even if it is offering synergies between different water demands and users at a specific location [7].

In recent years, the government of Rwanda has defined a National Agricultural Policy whose main objective is to transform subsistence agriculture to modern agriculture but some factors, mainly droughts and mismanagement of rainwater in some parts of the country and this stopped the way for achieving the main objective [8].

Reason why this thesis aims to evaluate the use of hillside rainwater harvesting ponds on agricultural production, the outcome of the study will contribute to the understanding of how adoption water ponds would change the smallholder farmers' lives.

\section{Materials and Methods}

During this study both primary and secondary data was collected using survey, interview, focus group discussion and observation. The research design to obtain data for this study was cross-sectional and was designed as follow:
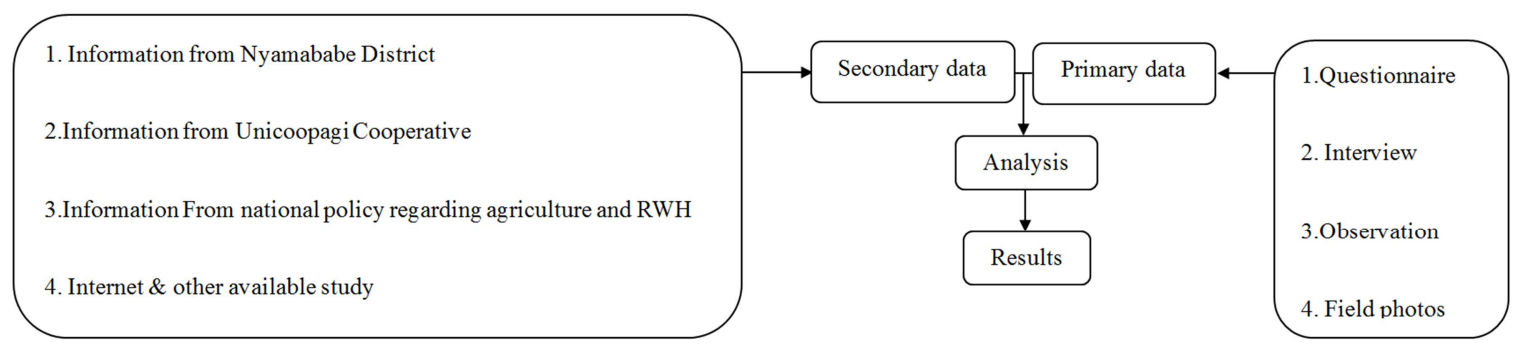

Figure 1. Research Design.

\subsection{Data Analysis Procedures}

After the collection of the data we processed and analyzed them. We examined the raw collected data to detect errors and omissions, and correct them when necessary and possible. The data collected has been put in suitable tabulation and suitable graphs, and figures for analysis.

For survey questionnaire, coding booklet has been produced to assist in the analysis. The questions in the questionnaires was pre-coded and later tabulated. Tabulation was done so as to draw out the main themes according to individual questions in the questionnaire. Tables produced from the code booklet sought to draw out some statistical representation of variables that the questionnaires attempted to generate.

The presentation of data in the forms of tables and graphs only facilitates proper and easy analysis of data. The obtained data were managed in SPSS and Microsoft Excel in order to evaluate the relationship hillside rain water harvesting ponds and agriculture production and later subjected to the analysis of variance (ANOVA) by using GENSTART statistical package and the means were significantly separated by using Duncan's Multiple Ranges Test (DMRT) and the Least Significant Difference (LSD) has been considered at 0.05 level of confidence. Differences at probability less than 0.05 were considered significant.

\subsection{Situation and Physical Characteristics of the Study Area}

Nyamagabe is one of the 8 Districts comprising the Southern Province. It is surrendered by the Districts of 
Karongi and Ruhango in the north, Nyanza and Huye on the East, Nyaruguru in the South, Rusizi and Nyamasheke on the West. Nyamagabe District is subdivided into 17 administrative Sectors, including Tare sector where the research took place, 92 Cells and 536 Villages. Tare sector is composed of six cells: Gasarenda, buhoro, nyamigina, nkumbure, kaganza and Gatovu. The study has been conducted in Nyamigina cell: Ngororero, uwinyana and nyamigina villages. The hydrograph of Nyamagabe District is subdivided into two basins: On one hand is the Rukarara river basin where rivers Kato and Nyagisenyi are located. On the other hand is river Mwogo basin with rivers Gihimbi,
Nyamugali and Nkungu. Nyamagabe District hydrography is equally characterized by several seasonal rivers [9].

The climate of Nyamagabe District is humid tropical and moderated by the effect of high altitude. Nyamagabe District is among the regions in the country with the highest rainfall. The annual rainfall varies from 1300 to $1450 \mathrm{~mm}$ with average temperature of $18^{\circ} \mathrm{C}$. The climate comprises, essentially, four seasons spread throughout the year as follows: two dry seasons stretching from January to February and from July to midSeptember and two rainy seasons from mid-September to December and from March to June. The District has an average altitude varying from 1800 to 2700 meters [10].

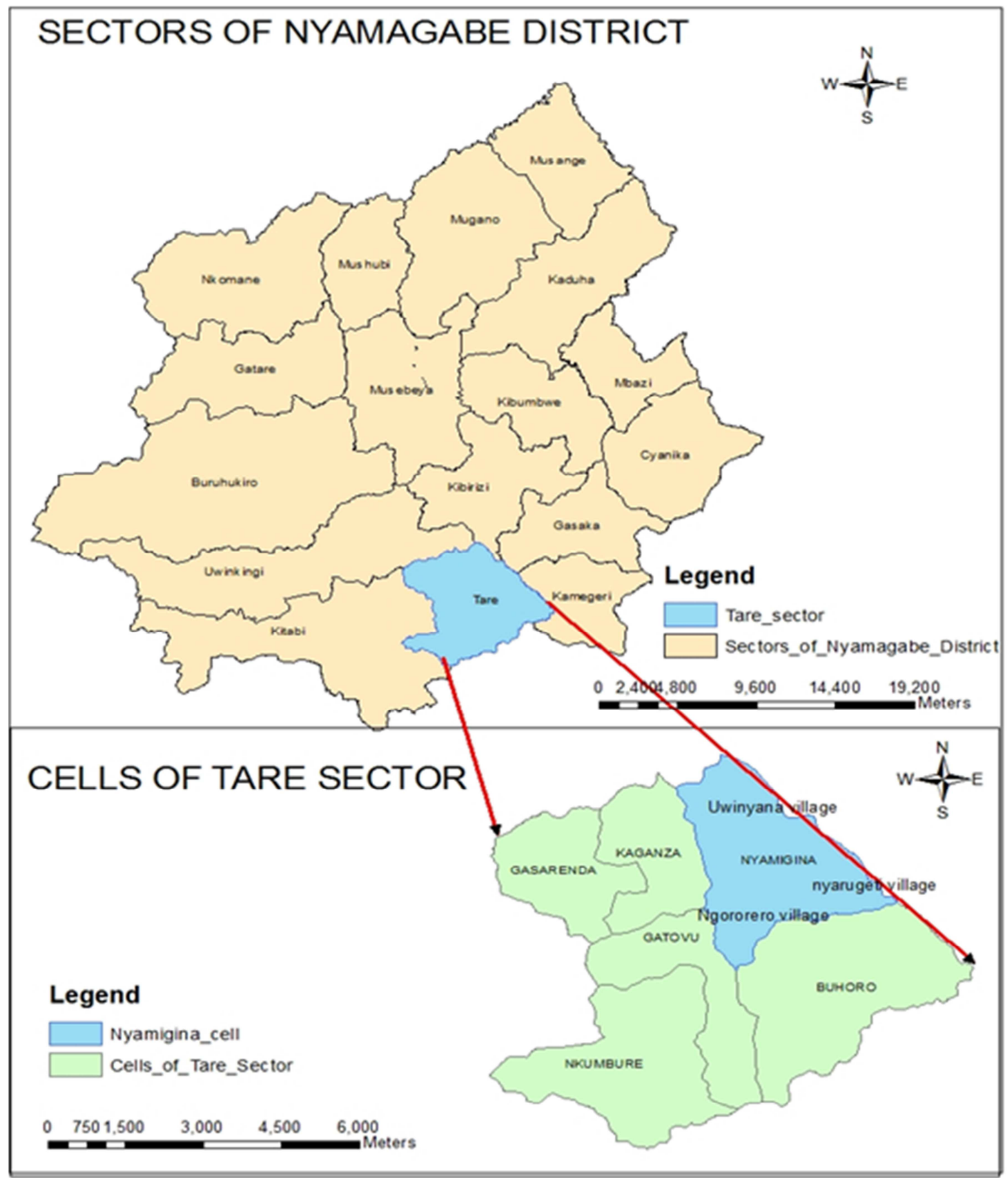

Figure 2. Map of Nyamagabe District. 


\section{Results}

\subsection{Factors Influencing the Adoption of Rainwater Harvesting Ponds Technology}

\subsubsection{Size of Plot Land}

In the survey done it is clear that among 197 farmers $59.9 \%$ has less than 0.5 hectares of available arable land, see table below.

Table 1. Land acquisition of farmer in UNICOOPAGI Cooperative union.

\begin{tabular}{llllll}
\hline & & Frequency & Percent & Valid Percent & Cumulative Percent \\
\hline \multirow{3}{*}{ Valid } & Less than 0.5ha & 118 & 76 & 59.9 & 59.9 \\
& between $0.5-1$ ha & 3 & 38.6 & 38.6 & 59.9 \\
& $1-2$ ha & 197 & 1.5 & 1.5 & 100.5 \\
& Total & 100.0 & 100.0 & 100.0 \\
\hline
\end{tabular}

This shortage of land area for practicing agriculture activities slow down the adoption of the use of RWH ponds; as show in the below photo the land size of 36 square meter was required to installer rain water harvesting pond of 250 cubic meter. The dam sheet was made in Polythene rolls of $0.8 \mathrm{~mm}$.
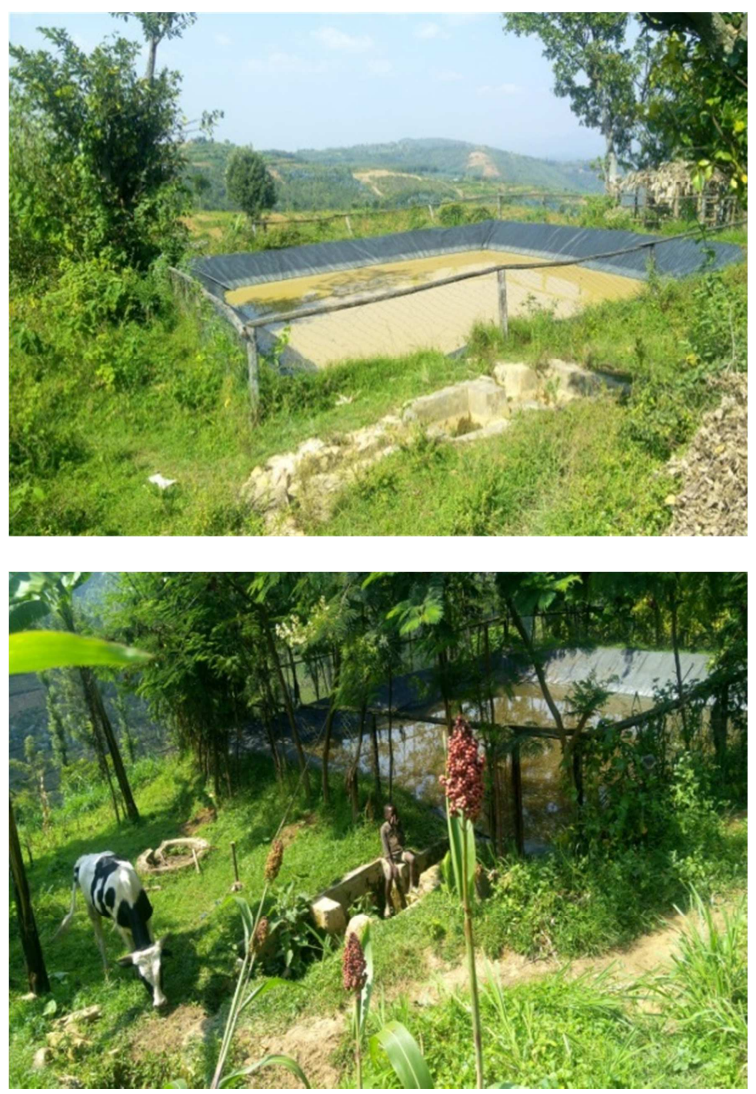

Figure 3. Installed dam sheet used in RWH Pond.

[11] Argue that the variable that were significant in explaining of adoption of RWH techniques are farm size, number of family members working in the farm, experience in farming and extent of knowledge in rain water harvesting techniques. Farmers with large farm size are likely to be able to take risks of adopting new technology. In Tanzania the intensity of using RWH technology was $50 \%$ high in Kifaru village compared to Lembini village due to the size of arable land.

\subsubsection{Use in Irrigation of Crops}

During field survey, we found that rain water harvesting pond was used mainly to irrigate crops during rainfall shortage. Among 102 farmers who adopted the use of RWH ponds during their agriculture activities, see figure $3 ; 80.4 \%$ of farmers use water to irrigate vegetables (cabbage, carrot, tree tomatoes and amaranths) other crops such as wheat, Irish potatoes and fruit trees was irrigated at a percentage of $19.6 \%$ as illustrated in the table 2 below:

Table 2. Irrigated crops through RWH Ponds.

\begin{tabular}{lll}
\hline Crop type & number of farmers & Percentage \\
\hline Cabbage & 27 & 22.5 \\
Carrot & 21 & 20.6 \\
tree tomato & 19 & 18.6 \\
Amaranths & 15 & 14.7 \\
other crops & 20 & 19.6 \\
Total & 102 & 100 \\
\hline
\end{tabular}

The main reason given is that vegetables crops are planted at a large size of land compared to others crops, and in dry agriculture season (season C) which start from July to September for every year in Rwanda.

Table 3. Location of installed rain water ponds.

\begin{tabular}{lllll}
\hline Altitude & Latitude & Longitude & $\begin{array}{l}\text { Dams/wate } \\
\text { r ponds }\end{array}$ & Dam size \\
\hline $2106 \mathrm{~m}$ & 9722900 & 0445699 & Dam1 & $250 \mathrm{~m}^{3}$ \\
$2144 \mathrm{~m}$ & 9722982 & 0445459 & DAm2 & $250 \mathrm{~m}^{3}$ \\
$2143 \mathrm{~m}$ & 9723019 & 0445368 & Dam3 & $250 \mathrm{~m}^{3}$ \\
$2016 \mathrm{~m}$ & 9724332 & 0446839 & Dam4 & $250 \mathrm{~m}^{3}$ \\
$2054 \mathrm{~m}$ & 9724121 & 0446632 & Dam5 & $250 \mathrm{~m}^{3}$ \\
$2059 \mathrm{~m}$ & 9724034 & 0446605 & Dam6 & $250 \mathrm{~m}^{3}$ \\
$2113 \mathrm{~m}$ & 9723802 & 0446009 & Dam7 & $250 \mathrm{~m}^{3}$ \\
$2163 \mathrm{~m}$ & 9723655 & 0445656 & Dam8 & $250 \mathrm{~m}^{3}$ \\
$2132 \mathrm{~m}$ & 9723127 & 0446748 & Dam9 & $250 \mathrm{~m}^{3}$ \\
$2030 \mathrm{~m}$ & 9723393 & 0447413 & Dam10 & $250 \mathrm{~m}^{3}$ \\
$2047 \mathrm{~m}$ & 9723704 & 0447129 & Dam11 & $250 \mathrm{~m}^{3}$ \\
$2123 \mathrm{~m}$ & 9723296 & 0446402 & Dam12 & $250 \mathrm{~m}^{3}$ \\
\hline
\end{tabular}

\subsubsection{Level of Adoption of Rain Water Ponds by Local Population}

After conducting discussion at 197 farmers of UNICOOPAGI cooperative union we found that only 102 equivalent to $51.5 \%$ adopted rain water harvesting pond, whereas 95 farmers $(48.2 \%)$ did not adopt. See figure below. 


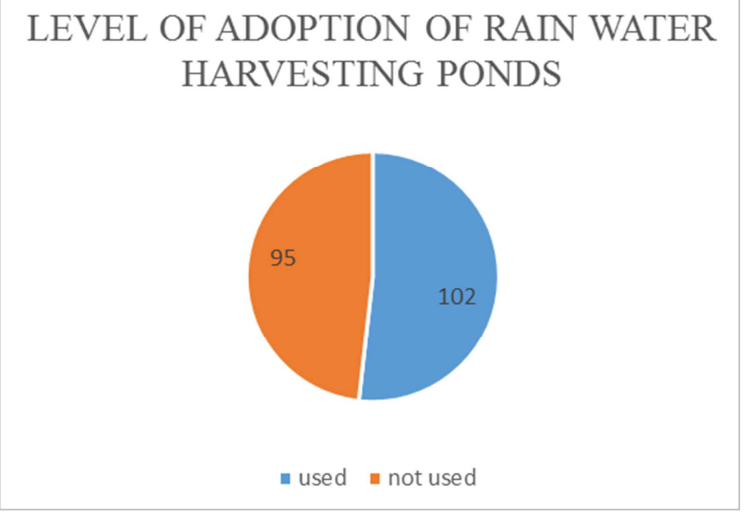

Figure 4. Level of adoption of RWH Ponds by farmers.

The main reason of not using rain water pond in agriculture was identified after the survey, and the reasons was insufficient space for pond excavation, lack of training about the role and use of rain water pond others were not chosen by the cooperative in order to used the installed water ponds. This is also the case of Ntarama, where the adoption of hillside irrigation in agriculture was at a low percentage of $42.5 \%$, and the main reason was the low level of public involvement during the site selection and lack of training about the role this technology [12].

\subsubsection{Negative Effect of Rain Water Harvesting Ponds}

Even though hillside rain water harvesting ponds have potential role in the improvement of farmer's activities, the conducted interview revealed that there is adverse effect like social conflicts, accidents and breeding site for mosquitoes. For 197 farmers interviewed, 81 equivalent to $41 \%$ said that RWH pond cause social conflict, 63 (32\%) said that it cause breeding of mosquitoes while 53 farmers equivalent to $27 \%$ stated that those pond cause accident of animals and children wishing to collect water.

The figure below illustrate the negative effect of rain water harvesting pond.

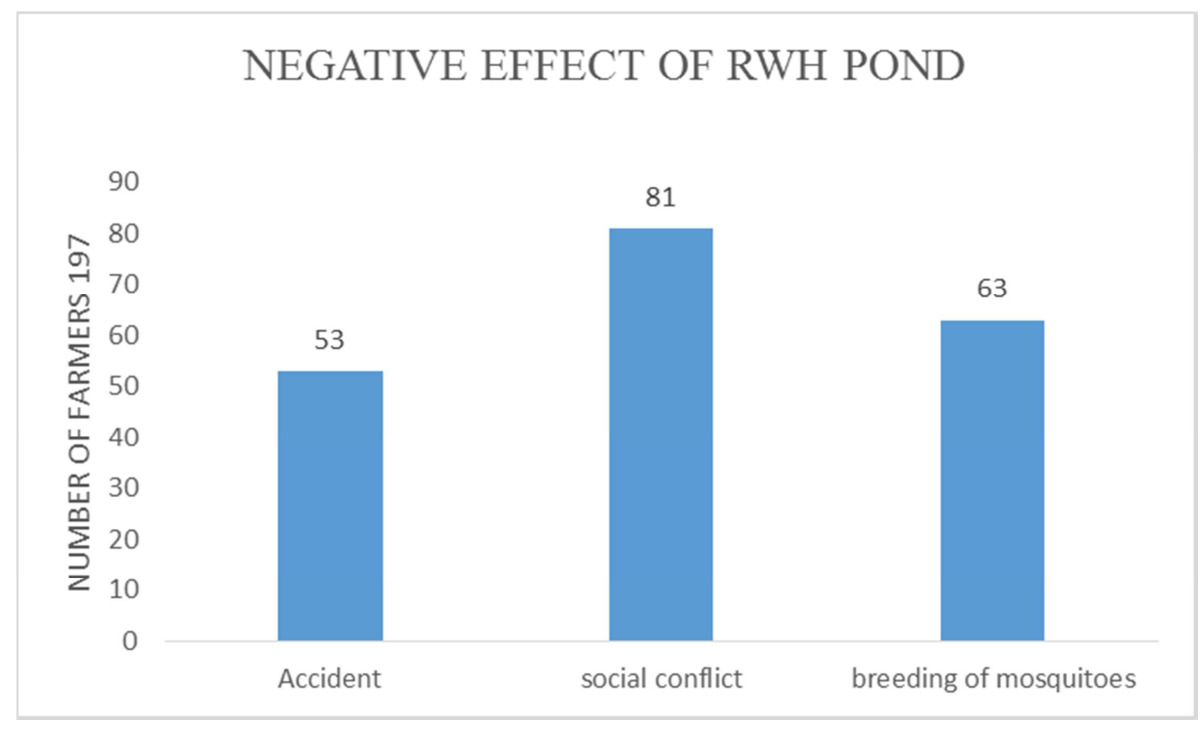

Figure 5. Negative effect of Rain Water Harvesting pond.

At social life point, conflicts which result among rain water harvesting ponds users are mainly related to those who wish to use water in other activities rather than farming. Also, some people who made their lands available for the construction of ponds do not want to share water with their neighbors which results in social conflicts among water users. So, there must be an intervention of leaders of UNICOPAGI cooperative union and local authority to eradicate those problems. This negative effect of breeding mosquitoes has also observed in the study carried in Ethiopia, besides rainwater harvesting is found to have undesirable, but not unexpected, health side effects. For instance many people and livestock have been drowned into the tanks and ponds, with often no fences and live saving mechanisms like ladder and ropes [13].

It is also cited by people living near the ponds as a source of malaria outbreak. However, it doesn't mean that rainwater harvesting didn't have any positive effects on the community. It has enabled them to grow crops of short growing periods like vegetables. And some have had good experience, as is the case in Tigray region where, for instance, "a farmer and his wife were able within a single season to pay their old extension credit of more than 1000 Birr through the planting and sale of vegetables (cabbages, tomatoes, beans and peppers) [14].

\subsection{Relationship Between Hillside Rain Water Harvesting Pond and Agriculture Productivity}

\subsubsection{Impact of Rain Water Harvesting Pond on Farmer Income}

As show on figure 5 income generated increased with the use of rain water harvesting pond from 2014 to 2018. From the data of production of UNICOOPAGI cooperative union, on the land size of 0.5 hectare income generated from irrigated land for the period of 4 years was 20,296,450 Frw whereas for non-irrigated land the generated income with the same land size was $17,772,800$ Frw.

Farmers testify that their level of living has been 
economically increased after incorporation of RWH Ponds in food for their families. their daily farming activities hence they have no shortage of

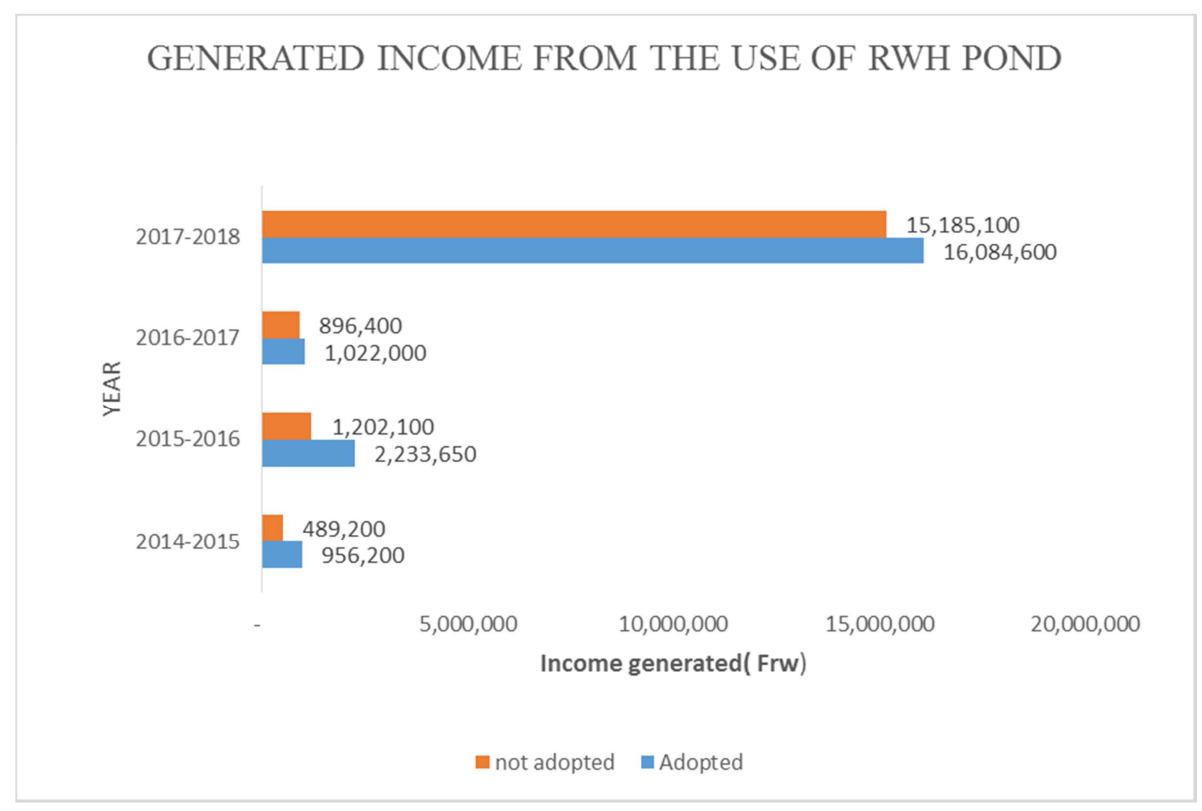

Figure 6. Generated income from the use of RWH pond.

\subsubsection{Increase of Agriculture Productivity}

The figure 6 illustrate the linkage between hillside rain water harvesting pond and agriculture productivity, based on the recorded data of UNICOOPAGI Cooperative union; it is clear that kilograms of crop production increased with the adoption of irrigation using water harvested in ponds for grown vegetable crops (Cabbage, Carrot, Amaranths and Tree Tomatoes).

The analysis of variance (ANOVA) results shows that the amount of agriculture production generated is significantly difference between adopted and non-adoption use of rain water harvesting ponds in agriculture. At income generated level $(\mathrm{p}=0.023)$ and for the quantity of produced crops $(\mathrm{p}$ $=0.004$ ), when comparing the results before adoption and after adoption of RWH Pond with the fixed level of confidence equivalent to $5 \%$, It is clear that there is a significantly difference between the two treatment.

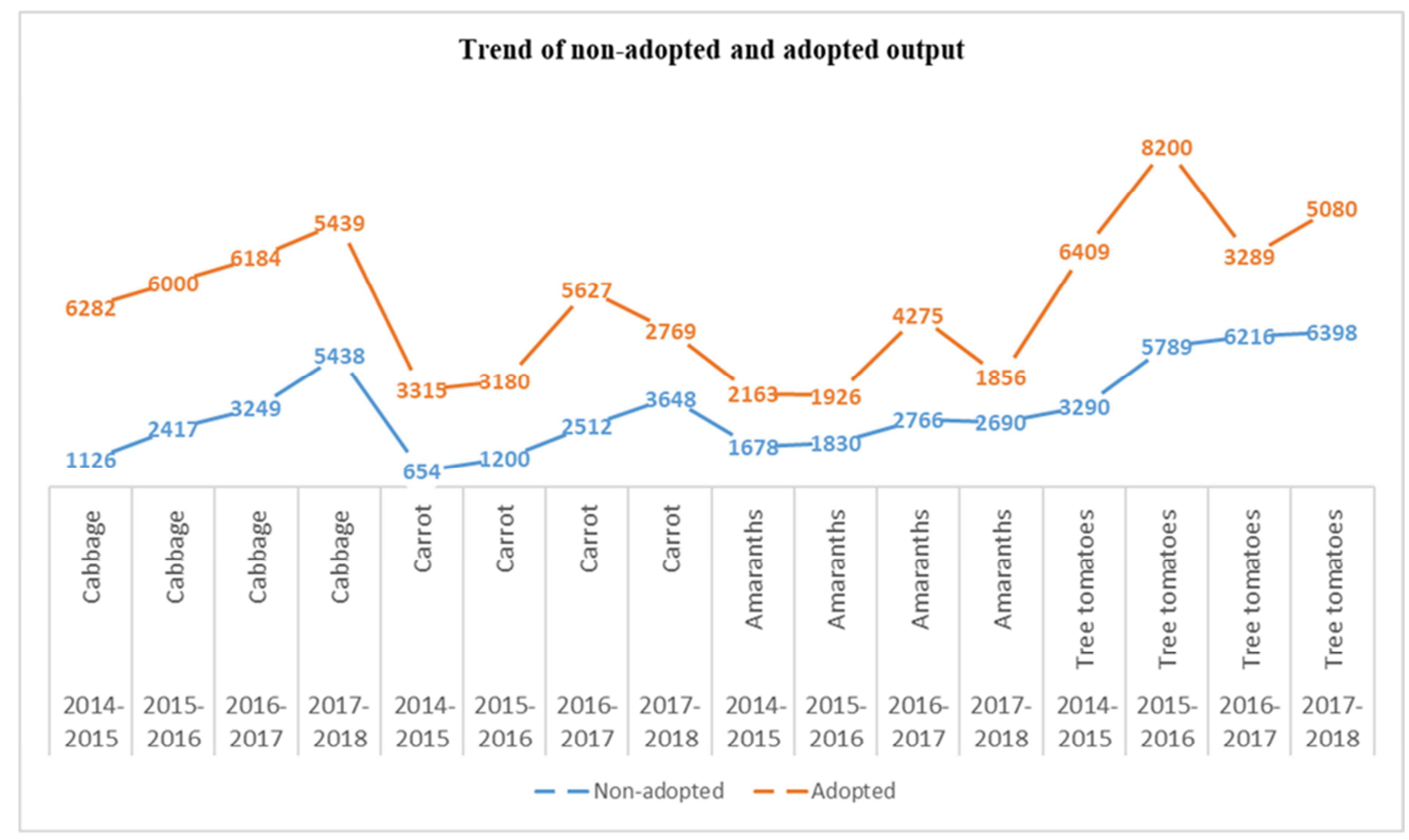

Figure 7. Agriculture production trend of non-adopted and adopted plot for RWH Pond. 
This increase of kilograms of agriculture production through the use of rain water harvesting technology has been also proved by the study of growing wheat in Dingxi whereby yield from irrigated treatment wheat was $50 \%$ higher than that from non-irrigated wheat crop [15].

In another study at the same site, 4 improved cultivars of corn (Zea mays) including Lindan 160, Lindan 141, Jiudan 3 and Danyu 13 were planted under the plastic film mulch condition. All the cultivars received supplemental irrigation of about $750 \mathrm{~m} 3$ per hectare during the earring stage (a most sensitive period to water stress), with a non-irrigated control. This study indicates that the average yields of irrigated cultivars were $20 \%$ higher than the no irrigated cultivars.

Furthermore, a field study involved in supplemental irrigation of rainfed fruit trees was also carried out at the same site. In this study, 3 cultivars of pear (Pyrus spp.) including Zaoshu, Jinfeng and Korea Yangli were used. All pear trees were irrigated 4 times using the subsurface drip irrigation during the period from flowering to fruit expanding stages, with a no irrigated control. This study shows that the average fruit yields per tree for the 3 irrigated cultivars were 26.2 (Zaoshu), 34.4 (Jinfeng) and $23.6 \mathrm{~kg}$ (Korea Yangli), with increases of 58,83 and $102 \%$ as compared with no irrigated trees. All these results suggest that implementing RWH practices can improve performance in rainfed farming systems in semiarid areas [16].

\section{Conclusion}

This research was conducted on the assessment of the use of hillside rainwater harvesting ponds on Agricultural Production; the primary data was collected using questionnaire survey, interviews and observation. The results from collected data showed that rain water harvesting ponds was used by $51.5 \%$ farmers; The main reason of failing level of RWH ponds is due to small plot size of farmers. It is further revealed that the use of rain water harvesting pond impacted positively the agriculture productivity, on 0.5 hectares/ 4 years the generated income was $17,772,800$ Rwandan Francs for non-irrigated plot, while with the same plot with the use of rain water harvesting in irrigation the income increased to 20,296,450 Rwf.

The analysis of variance (ANOVA) result shows that the amount of agriculture productivity is significantly difference between adopted and non-adopted rain water harvesting techniques. The implication of these findings is that the adoption of rainwater harvesting ponds presents a wayforwad for reducing rural poverty. With the increase of rainfall variability and evaporation due to climate change, rain water harvesting will become a key intervention in adaptation and in reducing vulnerabilities of crop water stress. Therefore, extent knowledge in RWH techniques need to be considered as an important, manageable resource in water management policies, strategies and plans. Considering that farmers perception in increasing crop yield is due to rain water harvesting, this will encourage the adoption of this techniques. Thus for the RWH techniques to be effective and bring higher return to farmers, it should go hand in hand with other improved agriculture inputs use such as seeds, pesticide and fertilizers.

\section{Recommendations}

This study has generated a number of issues and questions, it is clear that in terms of avoiding social conflict and increasing the adoption of RWH techniques with the aim to increase agriculture productivity the following recommendation have to be implemented:

Put in place rain water harvesting ponds user group in order to avoid social conflict resulting from the use of harvested water.

Implement land use consolidation strategy in order to have enough space to dig other rain water harvesting ponds.

Special attention should be given to fertilizer use, pest and diseases management strategies and the use of improved storage techniques in order to avoid post-harvest losses.

There is a need for policies and strategies that target on various ways of reducing the cost of adopting RWH technology so as to include the poorer farmers alongside the public involvement during ponds implementation in order to avoid the social conflicts arising among water users.

There is a need to conduct a feasibility study in order to know the crop water requirement before installation of rain water harvesting ponds.

Before installing water pond, there is a need to check for soil structure and water holding capacity as well as to provide the washout in case the dam is full of water in order to avoid flooding of agriculture plots below the installed dam.

There should be water users committee in order to avoid social conflict and accidents that may arise with the use of the installed water ponds.

Considering the benefit of use rain water harvesting pond in increasing agriculture production, policy makers should put in place a subsidy program for pro-poor farmers for installing rain water pond.

Farmers should also put in place saving mechanisms to enable them to maintain and install new rainwater harvesting ponds as well as to be able to purchase agriculture inputs.

\section{Acknowledgements}

Special thanks go to all UNILAK staff for constant help and cooperation received in setting up the study, I would like to express my thanks to all academic staff of Master of Science in Environment and Development Studies; Option of Environmental Economics and Natural Resources Management for their skills provided to accomplish my work.

Also my special thanks go to Mr Jean Marie Vianney Rukundo and RWABUKAMBIZA Venuste for the moral and every support they gave me. I feel highly indebted and full of gratitude to my Family, Colleagues, Friends and the farmers of UNICOOPAGI cooperative union for their great helps to 
reach on the end of this thesis. Last but not the least, my deep sense of gratitude is due to anyone who either directly or indirectly has contributed to the progress and financial assistance of this work.

\section{References}

[1] ECG (Evaluation Cooperation Group), (2011). "Evaluative Lessons for Agriculture and Agribusiness". Paper No.: 3. World Bank, Washington, DC.

[2] IEG (2010). "Growth and Productivity in Agriculture and Agribusiness: Evaluative Lessons from World Bank Group Experience". Washington, DC: World Bank.

[3] Ngigi, S. N. (2003) Rain Water Harvesting for Improved Food Security. Promoting Technologies in the Greater Horn of Africa. Greater Horn of Africa Rainwater Partnership (GHARP). Kenya Rainwater Association (KRA).

[4] MINAGRI (2007) Agricultural Rainwater Harvesting Interventions (ARWHI). Manual Final Report, Ministry of Agriculture and Animal Resources in collaboration with World Agroforestry Centre (ICRAF), Kigali. Published also by Hortfresh Jounal, 17, 14-15.

[5] PSTA-4 (2018). Strategic plan for agriculture transformation. Rwanda-Kigali 2018-2024

[6] RNRA, (2016). National rainwater harvesting strategy. Rwanda Natural Resources Authority, November 2016.

[7] Malesu, M., Oduor, A. R. and Odhiambo, O. J. (2008) Green Water Management Handbook: Rainwater Harvesting for Agricultural Production and Ecological Sustainability. World Agroforestry Centre ICCRAF, Nairobi, 229 p.

[8] Birasa, E. C., Bizimana, I., Bouckaert, W., Chapelle, J., Deflandre, A., Gallez, A., Maesschalck, G. E. T. and Vercruysse, J. (1990) Descriptions synthètiques des sols du Rwanda. C. P. R. et MINAGRI, Kigali.
[9] Nyamagabe District. (2013) District Development Plan, Rwanda.

[10] Nyamagabe District. (2018) District Development Strategy. Rwanda.

[11] Senkondo, E. M. M, N. S. Y Mdoe, N. Mahoo and J. Gowing. (2012). Factors affecting the adoption of Rain water harvesting technologies in Western pare lowlands of Tanzania. Sabinet gateway

[12] Munyaneza, O., Majoro, F., Hagenimana, E. and Usabyisa, W. (2016) Impact Assessment of Hillside Rainwater Harvesting Ponds on Agriculture Income: Case Study of Ntarama Sector in Rwanda. Journal of Water Resource and Protection, 8, 844854

[13] Hatibu N., Senkondo M., Mutabazi K. and Msangi K. (2004) "Economics of Rainwater Harvesting for Crop Enterprise in Semi-Arid Areas" downloaded from www.regional.org.au/cs/2004/symposia/1/4/276 hatibu.htm, accessed in December 2019.

[14] Kerr, J. M. and Kimberly, R. C., 2005. Evaluating Watershed Project Performance in India: A Practical Econometric Approach. In: Shiferaw, B., Freeman, H. A., and Swinton, S. M. (Eds.) Natural Resource Management in Agriculture: Methods for Assessing Economic and Environmental Impacts. UK: CABI Publishing in association with The International Crops Research Institute for the Semi-Arid Tropics (ICRISAT), Patancheru 502 324, Andhra Pradesh, India; 2005

[15] Li, F. M., Zhao, S. L., Duan, S. S., Gao, S. M. and Feng, B. 1995. Preliminary study on limited irrigation for spring wheat field in semi-arid loess region of China. China J. Appl. Ecol. 6, 259-264. (In Chinese, summary in English).

[16] Gao, S. M. and Zhu, R. S. 1996. Effects of supplemental irrigation and plastic film mulching on yields of rain fed crops. J. Arid Land Resources Environ. 2, 42-48. (In Chinese, summary in English). 